Ann. Biol. anim. Bioch. Biophys., 1978, 18 (1), 127-132.

\title{
Effect of lactose feeding on cell renewal, disaccharidase activity and calcium-binding protein content in the intestinal mucosa of rats
}

\author{
par Danielle PANSU, Claire BELLATON, Arlette BOSSHARD * \\ Ecole Prafique des Hautes Efudes and * Unité de Recherches de Physiopathologie digestive, \\ Pavillon $H$ bis, Hôpital Edouard Herriot, 69374 Lyon Cedex 2, France.
}

Summary. To determine how lactose increases calcium absorption and its retention in the skeleton, we measured intestinal mucosa structure, its disaccharidase and calciumbinding protein, $(\mathrm{CaBP})$ content and the empty liveweight calcium content. These measurements were carried out on rats eating a semi-synthetic diet since weaning containing 30 p. 100 lactose. In controls, carbohydrates were supplied in the form of starch and a vitamin D supplement was given. Administration of lactose caused cecum hyperplasia in ten 4-month old animals. The morphology, cell renewal rafe and disaccharidase content of the small intestine were unmodified as compared to control values. CaBP content, measured in control animals $2,3,4$, and 5 months old, decreased with age in the duodenum. CaBP disappeared from the jejunum and ileum at 3 months of age. When a diet containing lactose and vitamin D was given, CaBP content decreased at all levels and disappeared from the duodenum when the rats were 5 months old. As compared to the pair-fed controls, calcium content of the whole aimal, deprived of vitamin $D$ and given calcium, was the same in ten 4-month old rats and higher in seven 12-month old subjects. The administration of lactose caused no changes in the small intestine which could explain the increased absorption and retention of calcium. The decrease in CaBP content indicated that lactose increases absorption by a mechanism which is not related to active vitaminodependent transfer.

\section{Introduction.}

Lactose and other sugars as xylose, mannose, arabinose increase the absorption and retention of calcium in rats when the sugar is incorporated into the died (Dupuis and Fournier, 1964). On the contrary, when the sugar is injected into the lumen of the intestinal ligated loop, the absorption of calcium increases only if the test solutions containing the calcium salt and the sugar are hyperosmotic. The effect is non-specific and a similar increase is obtained using glucose (Vaughan and Filer., 1960) or a solution of $\mathrm{NaCl} 1200 \mathrm{mM}$ (Pansu et al., 1976). To explore the role of the previous ingestion of lactose, the present study investigates the intestinal status of rats receiving lactose as 30 p. 100 of the diet from weaning. 


\section{Material and methods.}

Animals and diets. - Male Wistar rats were placed on a semi-synthetic diet from weaning ; this dief contained 18 p. 100 vitamin D-free casein, 8 p. 100 arachid oil, a salt mixture of 0.52 p. $100 \mathrm{Ca}$ and 0.34 p. $100 \mathrm{P}$, vitamin supplement with or without $50 \mathrm{IU} / 100 \mathrm{~g}$ vitamin D. Carbohydrates were given as $67 \mathrm{p} .100$ starch or as $37 \mathrm{p} .100$ starch and 30 p. 100 lactose. Three combinations were obtained : « vitamin $D »$ dief in which rats considered as control animals received starch and vitamin D, « lactose diet» in which rats received 30 p. 100 lactose and no vitamin D, «lactose + vitamin D » diet in which rats received together 30 p. 100 lactose and vitamin D. Paired rats were killed at the age of 4 months for enzymatic and autoradiographic studies, at 2 , 3, 4 and 5 months for Calcium-Binding Protein (CaBP) assay, and at 4 and 12 months for skeletal calcium measurement.

Collection of specimens. - The intestine was divided into three parts, the first $15 \mathrm{~cm}$ were designated as the duodenum, the remaining segment was sectioned into two equal parts, the upper one being designated as jejunum, the lower part as ileum. The ascendent portion of the large intestine was taken as cecum.

Methods.

For autoradiographic studies, the rats received an intraperitoneal injection of $0.5 \mu \mathrm{Ci} / 100 \mathrm{~g} \mathrm{~B}$. W. $3 \mathrm{H}$ thymidine $30 \mathrm{~min}$ before they were killed. A $10 \mathrm{~mm}$ specimen was taken at the oral part of each previously-described segment and embedded in epon. Autoradiographs were realized on $2 \mu$-thick sections, covered with an llford K5 emulsion and developed after 21-day exposure. The labelling index is the percentage of labelled nuclei counted in the proliferative compartment; the mitotic index is the percentage of mitotic figures observed at the same site. The proliferative compartment was previously defined as the first 30 cells in the intestinal crypt (Pansu ef al., 1974). The indices were determined for a tolal of 20 crypis, i.e. 40 columns of 30 cells for each specimen.

For the enzymatic studies, the mucosa of each segment was scraped, weighed and homogenized in ice-cold water using a Potter homogenizer. The following factors were measured : DNA by Croft's method, proteins by Lowry's method, lactase (EC 3.2.1.23) and invertase (EC 3.2.1.26) activities by Dahlqvist's method (1968). Enzymatic activities were reported in milliUnits per $\mathrm{mg}$ of protein ( 1 milliUnit $=1$ nanomole of substrate hydrolyzed per min.).

Calcium-Binding Protein fractionation and measurement were realized using the technique of Freund and Bronner (1975). The pooled scraping of 6 duodenal, jejunal or ileal segments was homogenized in a Tris $\mathrm{HCl}$ buffer, centrifuged $100,000 \mathrm{~g}$ for $60 \mathrm{~min}$. The supernatant was chromatographed on a Sephadex $\mathrm{G} 50$ column. Peak B $\left(\mathrm{V} 2 / \mathrm{V}_{\mathrm{o}}=2\right)$ of the calcium-binding profile, including the intestinal CaBP of the rat, was determined quantitatively ; using Chelex resin, calcium-binding capacity was measured with a competitive binding assay by saturation kinetics. Linearization by the Michaelis Menten transformation permitted us to compute the maximum binding capacity expressed as nanomoles of $\mathrm{Ca}$ bound per $\mathrm{mg}$ of protein, and the dissociation 
coefficient $\mathrm{Kd}$, i.e. the concentration of free calcium when one-half of the sites are saturated.

Body calcium content was measured in ashes of eviscerated rats incinerated in a furnace at $600^{\circ} \mathrm{C}$ for $48 \mathrm{hrs}$. Ashes were solubilized in $\mathrm{HCl}$ and the calcium measured by the complexon technique using EDTA and Patton and Reeder's indicator (1956).

\section{Results.}

Qualitative data are shown in table 1. Prolonged lactose feeding induced significant cecal hypertrophy without hyperplasia of the mucosa. The weight of the cecum increased, but mucosal weight and DNA content per $1 \mathrm{~g}$ of the organ were similar $(143 \mathrm{mg} / \mathrm{g}$ and $0.88 \mathrm{mg} / \mathrm{g}$ in lactose-fed rats and $160 \mathrm{mg} / \mathrm{g}$ and $0.92 \mathrm{mg} / \mathrm{g}$ in control rats, respectively). Labelling and mitotic indices were not altered as compared with those of control rats.

\section{TABLE 1}

Quantitative studies of the intestinal mucosa of 4-month old rats.

Each value represents the mean $\pm S E M$. Number of cases are indicated in parentheses

\begin{tabular}{|c|c|c|c|}
\hline Diet & Vitamine D & Lactose & $p$ \\
\hline Age (in month) $\ldots \ldots \ldots \ldots \ldots$ & 4 & 4 & \\
\hline Body weight $(g) \quad \ldots \ldots \ldots \ldots$ & $304 \pm 11,4(10)$ & $288 \pm 12(10)$ & NS \\
\hline \multicolumn{4}{|l|}{ Wel weight $(\mathrm{mg})$} \\
\hline 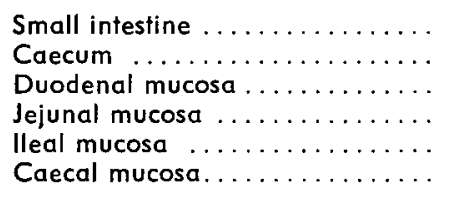 & $\begin{aligned} & 7,620 \pm 330(5) \\
& 800 \pm 100(5) \\
& 97 \pm 10(10) \\
& 1,178 \pm 188(10) \\
& 1,029 \pm 112(10) \\
& 131 \pm 0.001(10)\end{aligned}$ & $\begin{array}{l}7,240 \pm 660(5) \\
1,560 \pm 160(5) \\
120 \pm 10(9) \\
1,170 \pm 156(9) \\
1,060 \pm 117(10) \\
223 \pm 0.017(10)\end{array}$ & $\begin{aligned} & N S \\
& P<0,05 \\
& N S \\
& N S \\
& N S \\
& P<0,01\end{aligned}$ \\
\hline \multicolumn{4}{|l|}{ DNA content (mg) } \\
\hline 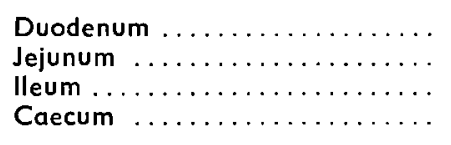 & $\begin{array}{l}0.697 \pm 0.053(10) \\
8.00 \pm 1.220(10) \\
7.55 \pm 0.92(10) \\
0.739 \pm 0.068(10)\end{array}$ & $\begin{array}{l}0.896 \pm 0.109(9) \\
7.40 \pm 1.02(10) \\
6.40 \pm 0.72(10) \\
1.38 \pm 0.163(10)\end{array}$ & $\begin{array}{l}\text { NS } \\
\text { NS } \\
\text { NS } \\
\mathrm{P}<0,05\end{array}$ \\
\hline \multicolumn{4}{|l|}{ Labelling index (p. 100) } \\
\hline $\begin{array}{l}\text { Duodenum } \ldots \ldots \ldots \ldots \ldots \ldots \ldots \\
\text { Jejunum } \ldots \ldots \ldots \ldots \ldots \ldots \ldots \ldots \ldots \\
\text { lleum } \ldots \ldots \ldots \ldots \ldots \ldots \ldots \ldots \\
\text { Caecum } \ldots \ldots \ldots \ldots \ldots \ldots \ldots\end{array}$ & $\begin{array}{l}33.81 \pm 1.83(7) \\
31.72 \pm 1.25(9) \\
31.71 \pm 1.4(9) \\
17.16 \pm 2.62(8)\end{array}$ & $\begin{array}{l}35.9 \pm 2.12(6) \\
30.11 \pm 1.03(8) \\
30.81 \pm 1.57(8) \\
17.92 \pm 1.66(9)\end{array}$ & $\begin{array}{l}\text { NS } \\
\text { NS } \\
\text { NS } \\
\text { NS }\end{array}$ \\
\hline \multicolumn{4}{|l|}{ Mitotic index (p. 100) } \\
\hline 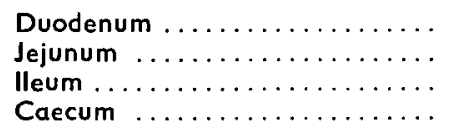 & $\begin{array}{l}6.37 \pm 0.235(7) \\
6.86 \pm 0.233(9) \\
7.77 \pm 0.26(9) \\
5.60 \pm 0.353(8)\end{array}$ & $\begin{array}{l}7.79 \pm 0.497(6) \\
6.60 \pm 0.57(9) \\
7.48 \pm 0.22(9) \\
5.91 \pm 0.524(8)\end{array}$ & $\begin{array}{l}P<0,05 \\
\text { NS } \\
\text { NS } \\
\text { NS }\end{array}$ \\
\hline
\end{tabular}


Intestinal disaccharidases. The specific activity of invertase was significantly higher in the duodenum $(36.1 \pm 2.33 \mathrm{mU} / \mathrm{mg}$ protein $)$ and cecum $(0.46 \pm 0.2 \mathrm{mU} / \mathrm{mg}$ protein) of lactose-fed rats than in control rats where activities reached $23.9 \mathrm{mU} / \mathrm{mg}$ protein and $0.23 \pm 0.1 \mathrm{mU} / \mathrm{mg}$ protein $(p<0.05)$, respectively. Computation of the fotal activity for each segment as shown in figure 1 indicates that the major activity is located in the jejunal and ileal segments where no differences were observed. Specific lactase activity was 20 times lower in control animals than invertase activity. In lactose-fed rats, the specific activity was significantly higher in ileum $(2.36 \pm$ $0.17 \mathrm{mU} / \mathrm{mg}$ protein) and in cecum $(0.58 \pm 0.20 \mathrm{mU} / \mathrm{mg}$ protein), but the total activity shown in figure 1 was quite similar in the two groups.

(1)
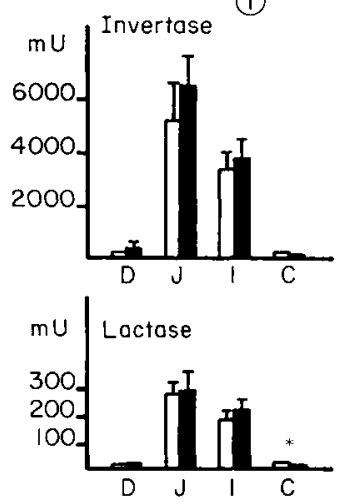

(2)

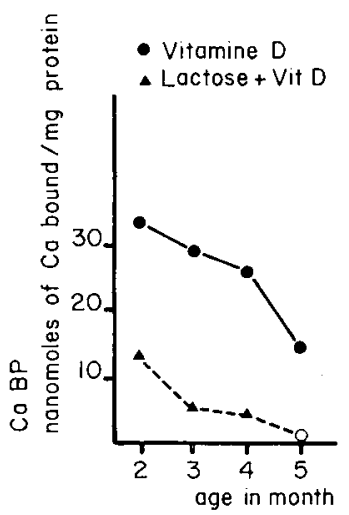

(3)

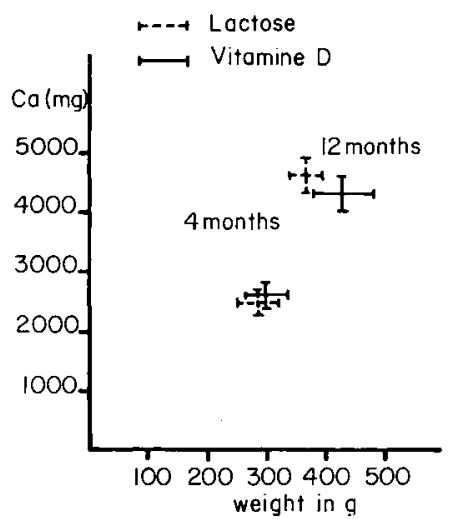

FIG. 1. - Total lactase and invertose activities in the mucosa of lactose-fed and 4-month old control rats. Duodenal measurements of 7 rats in both groups; jejunal, ileal and cecal measurement of 10 rats in both groups. Vertical lines indicate standard error of each determination. Activities are expressed as milli Units, i.e. nanomoles of substrate hydrolyzed per minute.

FIG. 2. - Duodenal calcium-binding protein levels as a function of age and diet. Every point is the mean of two determinations, each made on a pooled sample of 6 rat. — control rats ; - - - « Lactose + Vitamine $\mathrm{D}$ ॥ rats ; $\mathrm{O}=$ Peak detected, binding capacity not measurable.

FIG. 3. - Calcium content of the body related to age in control rat (-) and lactose-fed rats (- - -), n = 10 for both 4 -month old rats, $n=7$ for both 12 -month old rat. Vertical lines indicate standard error for Ca content ; horizontal lines indicate standard error for body weight.

Calcium-Binding Protein ( $\mathrm{CaBP}$ ) activity varied with age, intestinal segment, and diet. In 2-month old control rats, CaBP, expressed as nanomoles of calcium bound per milligram of protein, was 33.55 nmoles in the duodenum, 20.40 in the jejunum and 5.0 in the ileum. In 3-month old rats, the CaBP was 28.25 nmoles in the duodenum and detected but not measurable in the jejunum and ileum. CaBP totally disappeared from the ileum in 4-month old rats. In the lactose-fed rats receiving vitamin D simultaneously in order to permit synthesis of CaBP, the CaBP was lower in the duodenum and entirely absent in the jejunum and ileum of 2-month old rats. The CaBP concentration decreased quickly with age in the duodenum of lactose-fed rats, as shown in figure 2. The coefficient of dissociation $(\mathrm{Kd})$ varied from 0.5 to $1.2 \mathrm{mM}$ of calcium 
in all deferminations. This result indicated that a similar CaBP was tested and varied from concentration but not from Ca affinity.

Body Ca content. Feeding lactose permitted normal growth. In spite of vitamin D deprivation of 4-month old, lactose-fed rats, retention was equal to that observed in control animals. The Ca content per $100 \mathrm{~g}$ of body weight was $0.87 \mathrm{~g} / 100 \mathrm{~g}$ in lactosefed rats and $0.88 \mathrm{~g} / 100 \mathrm{~g}$ in control subjects. The calcium content was significantly higher $(1.23 \mathrm{mg} / 100 \mathrm{~g})$ in 12-month old, lactose-fed rats than in control animals $(1.0 \mathrm{~g} / 100 \mathrm{~g})(\mathrm{fig} .3)$.

\section{Discussion.}

Cecum hyperplasia, previously observed by Fournier and Guillam (1960) in mice and rats, involved a larger surface of cecal absorption. This hyperplasia was considered as an adaptation to the increased flux of water provoked by the lactose ; it did not increase the digestion and absorption of carbohydrates because the disaccharidase activities were extremely low. Hyperplasia is not necessary for increasing calcium absorption; the same increase was observed in rats after ablation of the cecum (Fournier, Susbielle and Dupuis, 1960).

Continuous lactose feeding did not induce a significant increase of the lactase level. This result confirmed the post-weaning decline observed by Leichter (1973) contrary to the significant induction measured by Fischer (1957).

The CaBP decrease is quite similar to that observed by Freund and Bronner (1975) in rats receiving a high calcium diet. This result could be explained as an adaptation to a high calcium entry into the pool, permitted by a higher absorption percentage. This regulation could be possible, considering the low 1.25 dihydroxycholecalciferol level observed in blood of rats receiving lactose (Boyle, Gray and De Luca, 1971). The low CaBP level did not inhibit calcium retention on the bone of young rats, and increased retention in older animals.

\section{Conclusion.}

The presence of lactose in the diet of rats deprived of vitamin D induces normal calcium retention and cecal hyperplasia with no change either in mucosal structure and renewal nor in small intestine lactase activity. These modifications do not explain the enhanced calcium absorption observed in vivo.

The low CaBP level proves that lactose increases calcium absorption by mechanisms independent of active calcium transport. The higher calcium content and urolithiasis observed in old rats (Gambier ef al., 1966) indicates increased absorption is not perfectly controlled. The exact mechanism remains unknown.

Réunion Groupe Développement INRA/Productions animales Montpellier, 17-18 mai 1977.

Acknowledgements. - This work was carried out under contract No 1908, A.T.P. Physiologie et Pathologie du Tissu Calcifié. 
Résumé. Pour préciser comment le lactose augmente l'absorption du calcium et sa rétention sur le squelette, on a mesuré chez des rats soumis depuis le sevrage à un régime semi-synthétique comportant 30 p. 100 de lactose la structure de la muqueuse intestinale, sa teneur en disaccharidases, et en protéine liant le calcium ( $\mathrm{CaBP}$ ) et le contenu en calcium du poids vif vide. Chez les témoins les glucides ont été apportés sous forme d'amidon et un supplément de vitamine $D$ a été assuré.

Chez 10 animaux de 4 mois l'administration de lactose entraîne une hyperplasie du caecum. La morphologie, la vitesse de renouvellement et la teneur en disaccharidases de l'intestin grêle ne sont pas modifiées par rapport aux valeurs trouvées chez les témoins.

La teneur en CaBP mesurée chez des animaux témoins âgés de 2, 3, 4 et 5 mois diminue avec l'âge dans le duodenum, la CaBP disparaît du jejunum et de l'iléon dès l'âge de 3 mois. L'administration d'un régime comprenant lactose et vitamine $D$ diminue la concentration en CaBP à tous les niveaux et une disparition de la $\mathrm{CaBP}$ duodénale chez le rat de 5 mois.

La teneur en calcium de l'animal entier privé de vitamine $D$ et recevant du lactose est identique chez 10 rats de 4 mois et supérieure chez 7 rats de 12 mois aux valeurs trouvées chez les animaux témoins appariés.

L'administration de lactose n'entraîne pas au niveau de l'intestin grêle de modifications susceptibles d'expliquer l'augmentation de l'absorption et de la rétention du calcium. La diminution de la teneur en CaBP permet d'affirmer que le lactose augmente l'absorption par un mécanisme indépendant du transfert actif vitaminodépendant.

\section{References}

BOYLE I. T., GRAY R. W., DE LUCA H. F., 1971. Regulation by calcium of in vivo synthesis of 1,25dihydroxycholecalciferol and 21,25-dihydroxycholecalciferol. Proc. not. Acad. Sci. USA, 68, 2131-2134.

CROFT D. N., LUBRAN M., 1965. The estimation of desoxyribonucleic acid in the presence of sialic acid and application to analysis. Biochem. J., 95, 612-620.

DAHLOVIST A., 1968. Assay of intestinal disaccharidases. Analyt. Biochem., 22, 99-107.

DUPUIS Y., FOURNIER P., L., 1964 . Etude comparée de l'action de la Vitamine $D$ ef du lactose sur les échanges calciques durant la vie du rat. C. R. Acad. Sci. Poris, Série D, 258, 2906-2909.

FISCHER J. E., 1957. Effect of feeding a diet containing lactose upon beta D galactosidase activity and organ development in the rat digestive tract. Amer. J. Physiol., 188, 49-53.

FOURNIER P., GUILLAM C., 1960. Influence de divers glucides sur le développement du tube digestif de la souris. J. Physiol. Paris, 52, 665-671.

FOURNIER P., SUSBIELLE H., DUPUIS Y., 1960. Propriétés biologiques du lactose et fermentations intestinales. Cas de l'ablation du caecum. C. R. Acad. Sci. Paris, Série D, 250, 1111-1113.

FREUND T., BRONNER F., 1975. Regulation of intestinal calcium binding protein by calcium intake in the rat. Amer. J. Physiol., 228, 861-869.

GAMBIER J., DUPUIS Y., GOURVITCH M., FOURNIER P., 1966. Variation du poids et de l'épaisseur des os du rat. selon la nature et la quantité ingérée de facteurs d'utilisation calcique. C. R. Acad. Sci. Paris, Série D, 263, 1500-1503.

LEICHTER J., 1973. Effect of dietary lactose on intestinal lactase activity in young rats. J. Nutr., 103, 392-396.

LOWRY O. H., ROSEBROUGH N. J., FARR A. L., RANDALL R. J., 1951. Protein measurement with the folin phenol reagent. J. biol. Chem., 193, 265-275.

PANSU D., BERARD A., DECHELETTE M. A., LAMBERT R., 1974. Effect of pentagastrin and secretin in the cell proliferation in the intestinal mucosa of the rat. Digestion, 11, 266-274.

PANSU D., CHAPUY M. C., MILANI M., BELLATON C., 1976. Tansepithelial calcium transport enhanced by xylose and glucose in the rat jejugnal ligated loop. Colcif. Tiss. Res., 21, 45-52.

PATTON J., REEDER W., 1956. New indicator for titration of calcium with ethylene dinitrilotetraacetate. Analyt. Chem., 28, 1026-1030.

VAUGHAN O. W., FILER L. J., 1960. The enhancing action of certain carbohydrates on the intestinal absorption of calcium in the rat. J. Nutr., 71, 10-14. 